\title{
Vegetation and Soil Carbon Storage of Some Typical Subtropical Evergreen Broad-leaved Forest in Dagang Mountain
}

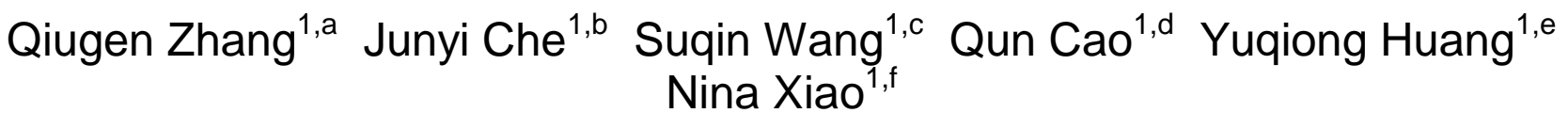

\author{
${ }^{1}$ School of Environment and Chemistry Engineering, Nanchang Hangkong University, 330063, \\ Nanchang, Jiangxi, PRC \\ a904644628@qq.com, b1085626289@qq.com, '81414770@qq.com, d365128286@qq.com \\ e1143327024@qq.com, ${ }^{\mathfrak{t}} 2574227335$ 4@qq.com
}

\section{Keywords: Dagang Mountain; Subtropical Evergreen Broad-leaved Forest; Organic Carbon Content; Carbon Storage; Carbon Density.}

Abstract. With the rapid development of human society and economy, the greenhouse effect caused by greenhouse gases had become one of the three major environmental problems in the world. Forest ecosystems mitigate the greenhouse effect by absorbing $\mathrm{CO}_{2}$ through the photosynthesis of green plants. Based on field investigation of three subtropical evergreen broad-leaved forests including Schima superba forest, Cyclobalanopsis glauca forest, and Castanopsis sclerophylla forest in Dagang Mountain Nature Reserve of Jiangxi Province, the vegetation and soil carbon storage and carbon density were calculated. The results showed that the organic carbon content of three subtropical evergreen broad-leaved forest species in the Dagang Mountain Nature Reserve was very close, and the content of organic carbon was between 0.47 and 0.49 . The order of organic carbon content in different organs was leaf $>$ stem $>$ branch $>$ root. The average carbon density of vegetation layer was $7.56 \mathrm{~kg} / \mathrm{m}^{2}$, and the carbon density of the arbor layer was $7.16 \mathrm{~kg} / \mathrm{m}^{2}$, the shrub layer was $0.17 \mathrm{~kg} / \mathrm{m}^{2}$, the litter layer was $0.15 \mathrm{~kg} / \mathrm{m}^{2}$, and the herb layer was $0.08 \mathrm{~kg} / \mathrm{m}^{2}$. The carbon density of the Schima superba forest was the highest which was $9.68 \mathrm{~kg} / \mathrm{m}^{2}$, the carbon density of the Cyclobalanopsis glauca forest was the smallest which was $6.44 \mathrm{~kg} / \mathrm{m}^{2}$, and the carbon density of the Castanopsis sclerophylla forest was $6.56 \mathrm{~kg} / \mathrm{m}^{2}$. The content of soil organic carbon in subtropical evergreen broad-leaved forest in Dagang Mountain Nature Reserve decreased with the increase of soil depth. The average soil carbon density was $20.926 \mathrm{~kg} / \mathrm{m}^{2}$, and the soil carbon density of Schima superba forest, Cyclobalanopsis glauca forest and Castanopsis sclerophylla forest was $16.634 \mathrm{~kg} / \mathrm{m}^{2}$, $29.554 \mathrm{~kg} / \mathrm{m}^{2}$ and $16.591 \mathrm{~kg} / \mathrm{m}^{2}$ respectively. The carbon storage of the standard samples of the Schima superba forest, Cyclobalanopsis glauca forest and Castanopsis sclerophylla forest were $14.971 \mathrm{t}, 26.599 \mathrm{t}$ and $14.932 \mathrm{t}$ respectively.

\section{Introduction}

With the development of social economy and improvement of people's living level, green housing gases over-polluted $\mathrm{CO}_{2}$ by human's social economical activities has caused greenhouse effect, which has threatened existence and development of human being's society. It is necessary to control the emission of greenhouse to slow down "green housing effect" for existence and development of humankind and society. Therefore, "carbon sink" issue of $\mathrm{CO}_{2}$ has been a key point of carbon storage study.

As an important part of global ecological system, forest ecological system plays an important role of carbon cycling regulation in global ecological system. Photosynthesis and respiration of forest plant have created favorable condition for carbon cycling of forest carbon storage.

Jiang xi Situates in subtropical region and Jiang xi province's forest coverage rate ranks the second in China. Evergreen broad-leaved forest is zonal vegetation in Dagang Mountain. Therefore, Dagang Mountain Nature Reserve was chosen as studying region, carbon storage and carbon density of several typical subtropical evergreen broad-leaved forest were calculated. It will have significance to 
maintain carbon balance in Jiangxi's ecological system and suppress green housing effect in this region.

\section{Overview of the Study Area}

Dagang Mountain Natural Reserve is located in the central and western part of Fenyi County in Xinyu City, the geographical location is $27^{\circ} 30^{\prime} \sim 27^{\circ} 50^{\prime}$ North latitude, $114^{\circ} 30^{\prime} \sim 114^{\circ} 45^{\prime}$ East longitude .The reserve is a mountain of Wugongshan, and the ridge line is mainly north and south, and the main terrain is west high and east low, the terrain of the area changes large, and relatively high is $1 \mathrm{~km}$, the highest altitude is $1091.8 \mathrm{~m}$; the average annual temperature is $15.8 \mathrm{C}^{\mathrm{o}}$, the annual rainfall is $1590.9 \mathrm{~mm}$. The average annual amount of sunshine is $1656.9 \mathrm{~h}$; The Vertical zone spectrum of Dagang Mountain Natural Reserve is successive red soil, yellow-red soil, red-yellow soil, yellow soil and yellow-brown soil. Evergreen broad-leaved forest is the zonal vegetation in Dagang Mountain. The main vegetation is subtropical evergreen broad-leaved forest, including Castanopsis sclerophylla forest, Cyclobalanopsis glauca forest, Schima superba forest, Castanopsis fargesii forest, Castanopsis fabri forest, Carpinus turczaninowii forest, and so on ${ }^{[1-2]}$.

\section{Research Methods}

\section{Sample Plot Investigation}

Three subtropical evergreen broad-leaved forests distribution area of the Castanopsis sclerophylla forest, Cyclobalanopsis glauca forest and Schima superba forest were chosen in Dagang Mountain Natural Reserve. Three standard sample plots were set in each subtropical evergreen broad-leaved forest type by opposite angles method. Each standard sample plot was $30 \mathrm{~m} \times 30 \mathrm{~m}$. Three different $2 \mathrm{~m} \times 2 \mathrm{~m}$ shrubs samples were set in each forest standard sample plot. $1 \mathrm{~m} \times 1 \mathrm{~m}$ herbals sample and $1 \mathrm{~m} \times 1 \mathrm{~m}$ litter sample were set in the shrubs samples. Then the vegetation biomass and soil related to the vegetation and soil carbon storage in each standard sample plot was investigated.

One section was randomly selected in the standard sample, which was undisturbed lot and vegetation structure and soil were representative. A $100 \mathrm{~cm}$ deep soil profile was excavated. Then stratified at $0-10 \mathrm{~cm}, 10-20 \mathrm{~cm}, 20-30 \mathrm{~cm}, 30-50 \mathrm{~cm}$ and $50-100 \mathrm{~cm}$ along the soil profile and collected all layers soil by using the ring knife. At the same time, a small sample of $1 \mathrm{~m}^{2}$ was set up in each bush sample. The soil was drilled in the center position of each sample by $0-10 \mathrm{~cm}, 10-20 \mathrm{~cm}$, $20-30 \mathrm{~cm}, 30-50 \mathrm{~cm}$ and $50-100 \mathrm{~cm}$ though soils drill with a diameter of $9 \mathrm{~cm}$. Then three drilled soil of each layer in the same standard sample plot were mixed as a soil sample.

\section{Sample Lab Processing}

The plant samples collected during the survey were taken back to the laboratory, 24-hour drying under $85^{\circ} \mathrm{C}$, and then determine the dry weight, moisture content and biomass of the sample. Then cut it into the pulverizer and shatter, sift out $(100 \mathrm{mu}, 0.154 \mathrm{~mm})$. Put in a sealed seal bag; keep it in the dryer to be tested. The organic carbon content in plant tissue was measured in the element analyzer by the dry combustion method.

Soil samples obtained with the ring knife were dried under $105^{\circ} \mathrm{C}$ for 24 hours to constant weight. Then the moisture content and dry weight were measured. And soil bulk density was calculated. Soil samples obtained from 3 shrubs quadrats were unfolded in a ventilated room for about 15 days to let it dry naturally. Pick out the fine roots in the drying process. Gently crushed and sifted (100 mesh, 0.154 $\mathrm{mm}$ ) soil, and put it in a sealed bag which placed in a dryer for test. The content of soil organic carbon was determined by potassium dichromate oxidation-spectrophotometer.

\section{Calculation of Vegetation Biomass}

Arbor layer biomass

The biomass model was used to estimate the arbor biomass. In this paper, diameter at breast height, 
tree Height and $\mathrm{D}^{2} \mathrm{H}$ three factors were selected which were easy and high accuracy to measure. The regression equation of single-wood biomass of the typical subtropical evergreen forest in Jiangxi province was created through regression analysis. Then the biomass of the arbor layer in the whole sample plot was estimated by $D^{2} H$-biomass model which was $\ln (B)=0.0 .57 \ln \left(D^{2} H\right)+0.0529$.

Shrub layer biomass

In the sample plot, the biomass average value of three shrub sample unite area was selected as the biomass of the shrub sample unite area. Then the biomass of the shrubs sample plot by multiplying the sample plot area.

Herbaceous layer biomass

In the sample plot, the biomass average value of three herbaceous sample unite area was selected as the biomass of the herbaceous sample unite area. Then the biomass of the herbaceous sample plot by multiplying the sample plot area.

Litter layer biomass

In the sample plot, the biomass average value of three litter sample unite area was selected as the biomass of the litter sample unite area. Then the biomass of the litter sample plot by multiplying the sample plot area.

\section{Calculation of Soil Bulk Density}

Soil bulk density was calculated by Equation (1).

$$
P=\frac{M}{V-\frac{m}{\rho}}
$$

In the Equation (1): $\mathrm{P}$ is the soil bulk density $\left(\mathrm{g} \cdot \mathrm{cm}^{-3}\right), \mathrm{M}$ is the soil stoving quality $(\mathrm{g}), \mathrm{V}$ is the soil volume $\left(\mathrm{cm}^{3}\right), \mathrm{m}$ is the debris quality of soil $(\mathrm{g}), \rho$ is the debris density $\left(\mathrm{g} \cdot \mathrm{cm}^{-3}\right)$.

\section{Calculation of Vegetation and Soil Carbon Storage and Carbon Density}

Calculation of vegetation carbon storage and carbon density

In the standard sample plot, the carbon storage of each vegetation layer is calculated by the biomass of the vegetation layer multiplying the related organic carbon content. All the carbon storages of each vegetation layer were the vegetation carbon storage of the standard sample plot. The vegetation carbon storage of the standard sample plot was divided by the total area of the sample plot, which is the carbon density of the vegetation. The average value of the carbon storage and carbon density of all the samples was taken as the carbon storage and the carbon density of the standard sample.

Calculation of soil carbon storage and carbon density

The soil carbon density can be calculated by soil bulk density, organic carbon content and depth of soil layers, it was shown in Equation (2).

$$
\rho_{C}=P \times H \times C
$$

In the Equation (2): $\rho_{\mathrm{c}}$ is the soil carbon density $\left(\mathrm{t} \cdot \mathrm{hm}{ }^{-2}\right), \mathrm{P}$ is the soil bulk density $\left(\mathrm{g} \cdot \mathrm{cm}^{-3}\right), \mathrm{H}$ is the soil depth $(\mathrm{cm}), \mathrm{C}$ is organic carbon content $(\%)$.

The sum of carbon density of each soil layer is the total carbon density of the forestland soil. The soil carbon storage can be calculated by the soil carbon density multiplying standard sample area ${ }^{[3-5]}$.

\section{Results and Analysis}

\section{Vegetation Carbon Storage and Carbon Density}

Organic carbon content of main organs

The organic carbon content of main organs of several subtropical evergreen broad-leaved forests in Dagang Mountain was shown in table 1. 
Table.1 Organic carbon content of main organs of evergreen broad-leaved forest in Dagang Mountain

\begin{tabular}{|c|c|c|c|c|c|}
\hline \multirow[b]{2}{*}{ organ } & \multicolumn{5}{|c|}{ The carbon content $(\%)$} \\
\hline & Schima superba & Cyclobalanopsis & glauca & Castanopsis sclerophylla & Average value \\
\hline Leaf & 50.4 & 49.8 & & 49.3 & 49.8 \\
\hline Branch & 47.4 & 48.0 & & 47.5 & 47.6 \\
\hline Stem & 48.0 & 47.4 & & 49.1 & 48.2 \\
\hline Root & 47.5 & 44.9 & & 46.8 & 46.4 \\
\hline * Average value & 47.9 & 47.4 & & 48.5 & 47.9 \\
\hline
\end{tabular}

Note: * The average organic carbon content was the weight value of tree species biomass.

The table 1 showed that the organic carbon content of subtropical evergreen broad-leaved forest species in Dagang Mountain was castanopsis sclerophylla (48.5\%) > Schima superba (47.9\%)> Cyclobalanopsis glauca (47.4\%). The average organic carbon content of different broadleaf forest species was about 0.5 . It was close to the results of wang bing and other research ${ }^{[6]}$. The organic carbon content of different organs in the evergreen broad-leaved forest of Dagang mountain was leaf $(49.8 \%)>$ stem $(48.2 \%)>$ branch $(47.6 \%)>$ root $(46.4 \%)$. Evergreen broad-leaved forest tree species can enhance the forest carbon reserve capacity.

Vegetation carbon density

The carbon density of different vegetation layers in several subtropical evergreen broad-leaved forests was shown in table 2.

Table. 2 Carbon density of different vegetation layers in subtropical evergreen broad-leaved forest in Dagang Mountain

\begin{tabular}{ccccc}
\hline & \multicolumn{4}{c}{ The carbon density $\left(\mathrm{kg} / \mathrm{m}^{2}\right)$} \\
\cline { 2 - 5 } Vegetation layer & Schima superba forest & $\begin{array}{c}\text { Cyclobalanopsis } \\
\text { glauca forest }\end{array}$ & $\begin{array}{c}\text { Castanopsis } \\
\text { sclerophylla forest }\end{array}$ & Average carbon density \\
\hline Arbor layer & 9.24 & 6.08 & 6.17 & 7.16 \\
Shrub layer & 0.18 & 0.16 & 0.17 & 0.17 \\
Herb layer & 0.1 & 0.05 & 0.08 & 0.08 \\
Litter layer & 0.16 & 0.15 & 0.14 & 0.15 \\
Total density & 9.68 & 6.44 & 6.56 & 7.56 \\
\hline
\end{tabular}

The table2 showed that the average carbon density of subtropical evergreen broad-leaved forests in Dagang mountain was $7.56 \mathrm{~kg} / \mathrm{m}^{2}$, which was different from that of Wei Wenjun's research result $\left(3.091 \mathrm{~kg} / \mathrm{m}^{2}\right)^{[7]}$. It may be the difference of standard sample. The average carbon density of subtropical evergreen broad-leaved forests in the Dagang Mountain was Schima superba forest $\left(9.68 \mathrm{~kg} / \mathrm{m}^{2}\right)>$ Castanopsis sclerophylla forest $\left(6.56 \mathrm{~kg} / \mathrm{m}^{2}\right)>$ Cyclobalanopsis glauca forest $\left(6.44 \mathrm{~kg} / \mathrm{m}^{2}\right)$. The carbon density of arbor layer had an absolute advantage in the vegetation layer. The carbon density of different vegetation layers in the evergreen broad-leaved forest of Dagang Mountain was arbor layer $\left(7.16 \mathrm{~kg} / \mathrm{m}^{2}\right)>$ shrub layer $\left(0.17 \mathrm{~kg} / \mathrm{m}^{2}\right)>$ litter layer $\left(0.15 \mathrm{~kg} / \mathrm{m}^{2}\right)>$ herb layer $(0.08$ $\mathrm{kg} / \mathrm{m}^{2}$ ).

Carbon storage distribution of vegetation

The carbon storage of main organs of several subtropical evergreen broad-leaved forest in Dagang Mountain was shown in table 3.

Table.3 Carbon storage of main organs of evergreen broad-leaved forest in Dagang Mountain 


\begin{tabular}{cccc}
\hline & \multicolumn{3}{c}{ Carbon storage (t) } \\
\cline { 2 - 4 } organ & $\begin{array}{c}\text { Schima superba } \\
\text { forest }\end{array}$ & $\begin{array}{c}\text { Cyclobalanopsis glauca } \\
\text { forest }\end{array}$ & $\begin{array}{c}\text { Castanopsis sclerophylla } \\
\text { forest }\end{array}$ \\
\hline Leaf & 0.48 & 0.27 & 0.20 \\
Branch & 1.68 & 1.26 & 0.63 \\
Stem & 5.17 & 3.25 & 4.29 \\
Root & 0.98 & 0.69 & 0.44 \\
Total storage & 8.30 & 5.47 & 5.56 \\
\hline
\end{tabular}

Note: the calculation value of carbon storage was based on the sample area $\left(900 \mathrm{~m}^{2}\right)$.

It can be seen from table 3 that the carbon storage of subtropical evergreen broad-leaved forest in Dagang was Schima superba forest (8.3t) > Castanopsis sclerophylla forest (5.56t)> Cyclobalanopsis glauca forest (5.47t). The Schima superba forest had played an important role in the carbon balance of forest ecosystem.

It was basically consistent with carbon content of the main organ of the arbor layer of Schima superba forest, Cyclobalanopsis glauca forest and Castanopsis sclerophylla forest, that were basically stem $>$ branch $>$ root $>$ leaf. It showed that the carbon absorbed by plants through photosynthesis was mainly stored in stems and branches.

\section{Soil Carbon Content and Carbon Density}

Soil carbon content

The soil carbon content of subtropical evergreen broad-leaved forests in Dagang Mountain was shown in table4 and figure1.

Table.4 Soil Organic Carbon Content of Subtropical Evergreen Broad-leaved Forest In Dagang Mountain

\begin{tabular}{cccc}
\hline & \multicolumn{3}{c}{ Soil organic carbon content (\%) } \\
\cline { 2 - 4 } Depth $(\mathrm{cm})$ & Schima superba forest & $\begin{array}{c}\text { Cyclobalanopsis glauca } \\
\text { forest }\end{array}$ & $\begin{array}{c}\text { Castanopsis sclerophylla } \\
\text { forest }\end{array}$ \\
\hline $0-10$ & 7.99 & 12.54 & 8.07 \\
$10-20$ & 6.35 & 9.87 & 4.69 \\
$20-30$ & 3.86 & 7.70 & 4.49 \\
$30-50$ & 2.88 & 6.34 & 2.92 \\
$50-100$ & 2.29 & 4.71 & 2.26 \\
\hline
\end{tabular}

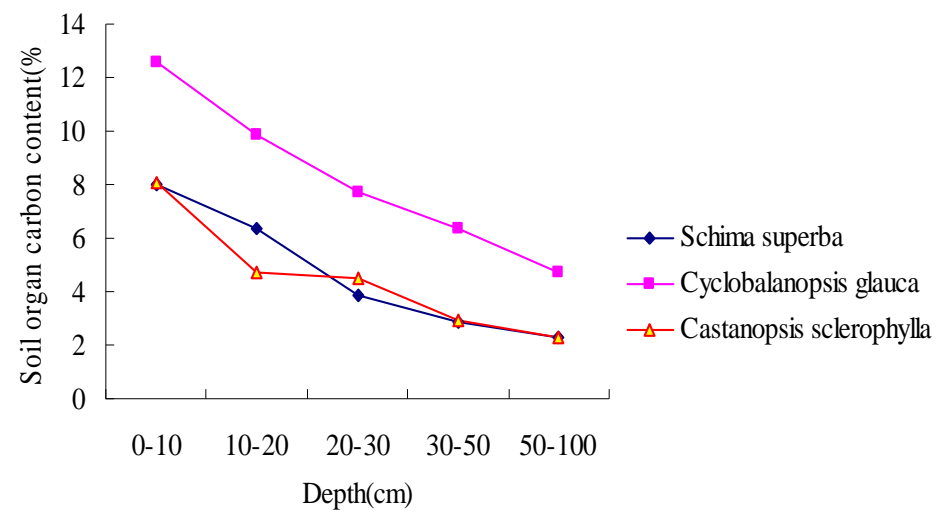

Fig.1 Soil organic carbon content of evergreen broad-leaved forest in Dagang Mountain

It could be seen in table4 and picture1 that the difference of soil organic carbon content changed with the change of forest vegetation type and soil depth. The sequence of soil organic carbon content of subtropical evergreen broad-leaved forest in Dagang Mountain ranged was Cyclobalanopsis glauca forest > Castanopsis sclerophylla forest > Schima superba forest. Carbon content of different soil layers decreased with the increase of soil depth.

Soil carbon density

Table.5 Soil Carbon Density of Subtropical Evergreen Broad-leaved Forest In Dagang Mountain 


\begin{tabular}{ccccc}
\hline & \multicolumn{4}{c}{ Soil carbon density $\left(\mathrm{kg} / \mathrm{m}^{2}\right)$} \\
\cline { 2 - 5 } Depth $(\mathrm{cm})$ & $\begin{array}{c}\text { Schima superba } \\
\text { forest }\end{array}$ & $\begin{array}{c}\text { Cyclobalanopsis } \begin{array}{c}\text { glauca } \\
\text { forest }\end{array} \\
\text { Castanopsis sclerophylla } \\
\text { forest }\end{array}$ & Average \\
\hline $0-10$ & 3.629 & 5.656 & 3.794 & 4.360 \\
$10-20$ & 3.071 & 4.879 & 2.220 & 3.390 \\
$20-30$ & 1.968 & 3.330 & 2.177 & 2.492 \\
$30-50$ & 2.818 & 5.67 & 2.973 & 3.820 \\
$50-100$ & 5.148 & 10.019 & 5.426 & 6.864 \\
Total & 16.634 & 29.554 & 16.591 & 20.926 \\
\hline
\end{tabular}

The soil carbon density of subtropical evergreen broad-leaved forest was shown in table5.It could be seen in table 5 that soil carbon density was different in soil layers. The average soil carbon density of different soil layer was $50-100 \mathrm{~cm}$ layer's $>0-10 \mathrm{~cm}$ layer's $>30-50 \mathrm{~cm}$ layer's $>10-20 \mathrm{~cm}$ layer's $>$ $20-30 \mathrm{~cm}$ layer's. It was calculated on average $10 \mathrm{~cm}$, soil carbon density in different soil depth decreased with the increase of soil depth, which was basically consistent with the change of soil organic carbon content.

Soil carbon density of subtropical evergreen broad-leaved forest was average $20.926 \mathrm{~kg} / \mathrm{m}^{2}$ in Dagang Mountain. Soil carbon density of Cyclobalanopsis glauca forest was $29.554 \mathrm{~kg} / \mathrm{m}^{2}$, Schima superba forest was $16.634 \mathrm{~kg} / \mathrm{m}^{2}$ and Castanopsis sclerophylla forest was $16.591 \mathrm{~kg} / \mathrm{m}^{2}$. It was indicated that the soil organic carbon storage of Cyclobalanopsis glauca forest was the largest in the evergreen broad-leaved forest in Dagang Mountain. Schima superba forest and Castanopsis sclerophylla forest were relatively in terms of the ability of organic carbon storage. The average carbon density of forest soil in China was $19.355 \mathrm{~kg} / \mathrm{m}^{2[8]}$, which indicated that the carbon density of Cyclobalanopsis glauca forest in Dagang Mountain was higher than the national average, and the carbon density of Schima superba forest and Castanopsis sclerophylla forest was lower than the average carbon density of forest soil in China.

Soil carbon storage distribution

The soil carbon storage of subtropical evergreen broad-leaved forests in Dagan Mountain was shown in table 6.

Table. 6 Soil carbon storage in subtropical evergreen broad-leaved forest in Dagang Mountain

\begin{tabular}{cccc}
\hline & \multicolumn{3}{c}{ Carbon storage (t) } \\
\cline { 2 - 4 } Depth (cm) & $\begin{array}{c}\text { Schima superba } \\
\text { forest }\end{array}$ & $\begin{array}{c}\text { Cyclobalanopsis glauca } \\
\text { forest }\end{array}$ & $\begin{array}{c}\text { Castanopsis sclerophylla } \\
\text { forest }\end{array}$ \\
\hline $0-10$ & 3.266 & 5.090 & 3.415 \\
$10-20$ & 2.763 & 4.391 & 1.998 \\
$20-30$ & 1.771 & 2.997 & 1.959 \\
$30-50$ & 2.536 & 5.103 & 2.676 \\
$50-100$ & 4.633 & 9.017 & 4.883 \\
Total & 14.971 & 26.599 & 14.932 \\
\hline
\end{tabular}

Note: The calculated carbon storages were based on the sample plot area $\left(900 \mathrm{~m}^{2}\right)$.

It was showed that the soil carbon storage of subtropical evergreen broad-leaved forest in Dagang Mountain was Cyclobalanopsis glauca forest > Schima superba forest > Castanopsis sclerophylla forest, which was consistent with the order of soil carbon density.

\section{Conclusions}

The organic carbon content of subtropical evergreen broad-leaved forest in Dagang Mountain Nature Reserve was very close, with the content ranging from 0.47 to 0.49 . The organic carbon content of different organs in three evergreen broad-leaved forests was leaf $>$ stem $>$ branch $>$ root. The average carbon density of forest vegetation layer was $7.56 \mathrm{~kg} / \mathrm{m}^{2}$, the carbon density of each forest layer was arbor layer> shrub layer> litter layer> herb layer. The carbon density of each forest were Schima superba forest > Castanopsis sclerophylla forest > Cyclobalanopsis glauca forest. The soil organic 
carbon content of subtropical evergreen broad-leaved forest in Dagang Mountain Nature Reserve decreased with the increase of soil depth. The soil carbon density of forest was Cyclobalanopsis glauca forest > Schima superba forest > Castanopsis sclerophylla forest, which was consistent with the content of soil organic carbon. The carbon storage of each forest standard sample plots was Cyclobalanopsis glauca forest > Schima superba forest> Castanopsis sclerophylla forest, which was in accordance with the carbon density of forest soil.

The total carbon storage of forest vegetation in the sample plots was 19.33t, the total carbon storage in forest soil was $62.779 \mathrm{t}$, and the carbon storage of forest soils was 3.25 times that of forest vegetation. The average carbon density of forest vegetation in the sample plots was $7.56 \mathrm{~kg} / \mathrm{m}^{2}$, the average carbon density of forest soil was $20.926 \mathrm{~kg} / \mathrm{m}^{2}$, and the average carbon density of forest soil was 2.76 times that of forest vegetation. The carbon density and carbon storage of forest vegetation was lower than that of forest soil. The main reason was that the vegetation layer involved in the forest ecosystem carbon cycle was relatively short, and the carbon of vegetation had fallen from the dead leaves into the upper layer of the earth, and it had entered the soil layer under the action of soil microorganisms. While the involvement of the soil layer in the ecosystem carbon cycle lasts longer and often requires conversion to atmospheric carbon under certain chemical conditions.

The carbon density of soil layer in Dagang Mountain Nature Reserve was $20.926 \mathrm{~kg} / \mathrm{m}^{2}$, the carbon density of arbor layer was $7.16 \mathrm{~kg} / \mathrm{m}^{2}$, the forest shrub layer was $0.17 \mathrm{~kg} / \mathrm{m}^{2}$, the herb was $0.08 \mathrm{~kg} / \mathrm{m}^{2}$, the litter was $0.15 \mathrm{~kg} / \mathrm{m}^{2}$, the carbon density of the soil layer was 2.93 times of the carbon density of the arbor layer.

\section{Acknowledgement}

This study was financially supported by National Natural Science Foundation of China (41463005).

\section{References}

[1] Li shaoning, Wang bing, Mr. Kwok, et al: China water and soil conservation science, Vol.5 (2007), p58

[2] Wang bing, Wang yan, Mr. Kwok, et al: Journal of Beijing forestry university, Vol.31(2009),p39

[3] Seedre M, Kopáček J, Janda P, et al: Forest Ecology and Management, Vol.346 (2015),p106.

[4] Domke G M, Woodall C W, Smith J E, et al:Forest Ecology and Management, Vol.270 (2012), p108

[5] Manninen S, Zverev V, Bergman I, et al: Science of the Total Environment, Vol.536(2015),p 616

[6] Bing Wang, Qing-Pei Yang: Guangxi Plant, Vol 31(2011),p342

[7] WenJun Wei: Master thesis of Inner Mongolia Agricultural University, 2007.

[8] HaiKui Li, YuanCai Lei: Forest Science, Vol 47(2011),p7 